\title{
Effect of Organic Loading Rate on the Biological Performance of the Thermophilic Anaerobic Membrane Bioreactor Treating Pulp and Paper Primary Sludge
}

\author{
Alnour Bokhary \\ Lakehead University - Thunder Bay Campus: Lakehead University \\ Mathew Leitch \\ Lakehead University - Thunder Bay Campus: Lakehead University \\ Baoqiang Liao ( $\sim$ bliao@lakeheadu.ca ) \\ Lakehead University - Thunder Bay Campus: Lakehead University
}

\section{Research Article}

Keywords: Biogas production, biological performance, primary sludge, anaerobic digestion, membrane bioreactor

Posted Date: June 1st, 2021

DOI: https://doi.org/10.21203/rs.3.rs-195625/v1

License: (c) (1) This work is licensed under a Creative Commons Attribution 4.0 International License. Read Full License

Version of Record: A version of this preprint was published at Clean Technologies and Environmental Policy on August 11th, 2021. See the published version at https://doi.org/10.1007/s10098-021-02186-w. 


\section{Abstract}

Waste-to-energy or value-added products have been increasingly considered in many pulp and paper mills (PPMs) worldwide. However, developing appropriate conversion technologies is a major challenge in transforming PPMs wastes into biofuels or value-added biomaterials. In the present study, a long-term (320 d) anaerobic digestion of primary sludge of a thermomechanical pulp mill (TMP) was carried out for the first time in a thermophilic anaerobic membrane bioreactor (ThAnMBR). Effect of organic loading rate (OLR) in the range of $2.5-6.8 \mathrm{~kg}-\mathrm{COD} / \mathrm{m}^{3} \mathrm{~d}$ and hydraulic retention times (HRT) of $3-8 \mathrm{~d}$ on the process performance was investigated. Under various OLRs, stable biogas productions were obtained, and the best results were achieved with lower OLR $\left(2.5 \mathrm{~kg}-\mathrm{COD} / \mathrm{m}^{3} \mathrm{~d}\right)$ and higher HRT $(8 \mathrm{~d})$, at biogas yields of $189 \mathrm{~L}$ biogas/kg MLSS fed. However, it was found that biogas production and sludge biomass degradation decrease when the organic loading rate increases. The proportion of sludge reduction ranged from 28.9 to $46.7 \%$ depending on the applied OLRs. Despite varying OLRs, stable membrane performance was obtained, where the required membrane flux was easily maintained during the reactor operation. In this study, also the properties of digestate and membrane permeates were studied under different operating conditions, and they fluctuated to some extent with OLR. ThAnMBR is a promising new technology for pulp and paper mill primary sludge treatment.

\section{Introduction}

Pulp and paper mill sludge (PPMS) represents a large part of the industrial waste and contains a high portion of the organic matter (Elliott and Mahmood, 2012). Sludge waste is produced from both virgin and recycled paper production processes (Simão et al., 2018). However, this substrate is usually undesirable and needs to be treated or disposed of in an environmentally acceptable manner. The common handling strategies of the waste sludge are landfilling, incineration, and recycling in the paper making process. The first two practices place a significant financial burden on the forestry industry because of the high capital expenses and high energy required to dry large amounts of water before burning the waste sludge (Meyer et al., 2018). Reportedly, sludge disposal takes a large part of the wastewater treatment facility budget ( $\approx \$ 30$ per wet ton), which may reach approximately $60 \%$ of the total cost (Elliott and Mahmood, 2012; Park et al., 2012). In addition to the high expenses, these traditional handling approaches have been characterized by several problems such as air (incineration) and water (landfill leachate) pollution. Conversely, PPM sludge contains valuable molecules (25-75\% carbohydrate). For example, Kraft PPM primary sludge is composed of woody materials such as cellulose (58 wt\%), hemicelluloses (12 wt\%), and lignin (20 wt\%), along with inorganic materials that have been used in the pulping process (Bayr and Rintala, 2012). While, the secondary sludge is composed of microbial biomass, cellulose (36-50 wt\%), and non-degradable lignin's compounds (19-44 wt\%) (Likon and Trebše, 2012; Kinnunen et al., 2015). The quantity of sludge production varies depending on the pulping processes, but primary sludge represents the majority of the total solids compared to secondary sludge (Bajpai, 2015). The application of traditional sludge treatment processes leads to the loss of these 
precious resources accompanied by environmental pollution (Bayr et al., 2013; Hazarika and Khwairakpam, 2018).

Several technologies, including direct combustion (Manwatkar et al., 2012; Pio et al., 2020a), pyrolysis (Yin et al., 2021), gasification (Pio et al., 2020b), and hydrothermal liquefaction (Zhang et al., 2021) processes have evolved to convert sludge waste into fuels. In addition to power generation, these technologies were characterized by reducing the volume of sludge, destroying harmful pathogens, and stabilizing heavy metals (Liew et al., 2012). However, the high initial investment cost and requirements for the pre-dewatering process hamper their wide application (Liew et al., 2012). Among the treatment alternatives, one strategy that has been recognized worldwide as a feasible option to improve the energy efficiency of PPM sludge is anaerobic digestion (AD). Anaerobic digestion (AD) offers a promising alternative relative to the above-mentioned options due to its reduced environmental footprint, small reactor size, and requires no sludge dewatering, where sludge dewatering represents a considerable economic burden. Also, the residual organic matter and nutrients that are retained in effluents (digestate) can be returned and reused for different applications (Veluchamy and Kalamdhad, 2017a).

The substrate's content of sugar, fat, and protein controls its anaerobic digestion potential and energy production; accordingly, PPM sludge appears an appropriate substrate for AD due to its high carbohydrate and high-water content. Also, one of the attractive features of PPM sludge is that the raw material cost is zero, no excessive pre-treatment is required due to previously processed biomass, and the possibility of using the existing pulp or paper mill equipment (Gurram et al., 2015). AD has been applied extensively and for a wide range of organic substrates. Nonetheless, the literature shows very limited studies treating PPM sludge as an anaerobic digestion substrate. Yet, studies on PPM sludge digestion are in their infancy and no industrial application has been reported to date. This may be due to long residence times (20-60 d), and low yield of bio-methane and bio-hydrogen due to its low degradability (30-50\%) (Lin et al., 2009; Kinnunen et al., 2015), plus the biomass separation problems of the traditional anaerobic digestion processes (Dereli et al., 2012). Additionally, effluent quality from anaerobic treatment is usually poorer than that from aerobic treatment and needs further polishing. This defect might limit the application of anaerobic technology, especially in places that require wastewater reclamation and reuse, such as an integrated forest biorefinery (IFB), where the resulting wastes and by-products are recycled and utilized as a resource.

Compared to traditional anaerobic digestion, the anaerobic membrane bioreactor (AnMBR), a combination of anaerobic digestion and membrane filtration, is a relatively new technology for the treatment of municipal and industrial wastes but has demonstrated its superiority over conventional anaerobic biological processes in terms of higher effluent quality for reuse/reclamation, recovery of most of the potential energy in biodegradable waste streams, and decoupling of solids retention time (SRT) from hydraulic retention time (HRT) (Bokhary et al., 2020). By integrating the membrane process for microbial biomass retention, anaerobic microorganisms can proliferate without being washed out of the system. This leads to higher biomass concentration in AnMBR, which may enhance biogas yield compared to conventional processes. Also, decoupling the HRT and SRT in AnMBRs can achieve a 
significant reduction in reactor volumes, thereby reducing capital costs. Thus, AnMBR could be a promising option for primary sludge digestion. However, to the authors' knowledge, no study has ever been reported on the treatment of pulp and paper primary sludge using thermophilic anaerobic membrane bioreactor (ThAnMBR) technology. Of the few experimental studies involving conventional anaerobic digestion of PPM sludge, only two studies tested PPM primary sludge (Jokela et al., 1997; Bayr and Rintala, 2012), while other studies focused on the treatment of secondary sludge, or sludge mixtures (Karlsson et al., 2011; Lin et al., 2011; Saha et al., 2011; Bayr and Rintala, 2012). Most PPM sludge studies have been conducted at mesophilic temperatures using batch assays, but few have been conducted in thermophilic conditions (Teghammar et al., 2012; Lopes et al., 2018). Bayr and Rintala (2012) examined AD of kraft mill primary sludge under thermophilic conditions using a semi-continuous bioreactor (CSTR) but at relatively long HRTs and low OLRs. OLR is an essential parameter and limited information is available about the steady-state performance of the ThAnMBR for biogas production under high OLRs.

Taking into account all the advantages of AnMBR mentioned above, the current research program focuses on the application of a relatively new ThAnMBR technology for biogas production from primary sludge of thermomechanical pulp (TMP) aiming for improving biogas yield and solids reduction and reducing HRT without the risk of washing out the microbial population. This study aimed to investigate the possibility of performing AD of TMP primary sludge at low HRT and high OLRs. Of interest is elucidating an optimal organic loading rate that maximizes bio-methane production and solids reduction, minimizes membrane fouling propensity, and produces permeate with suitable quality for reuse in a pulp and paper biorefinery.

\section{Materials And Methods \\ 2.1. Feed and inocula}

PPM sludge was obtained from a local Canadian thermomechanical pulp mill. Sludge received from this mill was dewatered sludge from a primary clarifier. The mill uses a mixture of hardwood and softwood as raw materials for pulp production. After delivered to the laboratory, the collected PPMS was stored in the refrigerator at $4^{\circ} \mathrm{C}$ before being prepared and used as a substrate. Primary sludge was mixed with tap water to create a slurry with a certain concentration as a feeding substrate. As primary sludges are relatively low in nitrogen and phosphorus (Hagelqvist 2013), ammonium chloride and dipotassium phosphate were added in COD: N: P of 100:2.6:1 ratio to improve its nutrients content. Table 1 shows the characteristics of the primary sludge and inoculum used in this study. The inoculum was collected from a thermophilic anaerobic membrane bioreactor operated for one year by a member of our research group (Jiang, 2018), and the system was treating secondary sludge from the local pulp and paper mill.

\subsection{Laboratory scale submerged AnMBR setup and operation}


The submerged AnMBR setup consists of a CSTR reactor with an active volume of $6.5 \mathrm{~L}$ and flat sheet microfiltration (MF) membrane module with an active surface area of $0.03 \mathrm{~m}^{2}(10 \mathrm{~cm} \times 15 \mathrm{~cm}$ on each side of the module) and pore size of $0.1 \mu \mathrm{m}$. The membrane material was a polyvinylidene fluoride (PVDF) (DAFU Membrane Technology Co., P.R. China). The bioreactor temperature was maintained at $50^{\circ} \mathrm{C}$ by circulating the warm water from an adjustable water bath through the water jacket of the reactor. The $\mathrm{pH}$ of the bioreactor was controlled at $7.2 \pm 0.1$ using a $\mathrm{NaOH}$ solution. For reactor feeding, the sludge was pumped into the bottom of the bioreactor by a feeding pump (Iwaki Magnet Pump, Iwaki co., LTD. Tokyo Japan). The pump was controlled by a water level sensor (Madison Co., USA), and a controller (Flowline, USA) to maintain a constant liquid level in the bioreactor. Figure 1 shows a schematic diagram of the ThAnMBR setup used in this study. After feeding the reactor with the required amount of inoculum and primary sludge, it was flushed with nitrogen gas for $5 \mathrm{~min}$ to create anaerobic conditions. Permeate was withdrawn from the system using a peristaltic pump (Masterflex C/L ${ }^{\circ}$, Cole-Parmer, Montreal, Canada), and collected in its tank for further analysis. The peristaltic pump was controlled by a timer that operated in three minutes on and two minutes off mode. Transmembrane pressure was monitored with a pressure gauge (Omega, model 656201BA4CD3ACD1. Korea). To sustain the required SRT, reactor sludge was taken out from CSTR once a day during the daily measurement of the biogas production rate, reactor $\mathrm{pH}$, and TSS of digestate.

For fouling control, the membrane was sparged by biogas. This was accomplished using a stainless-steel pipe diffuser placed below the membrane unit on each side, and the biogas was recirculated by two gas recycling pumps (Masterflex Console Drive, Model 7520-40, Thermo Fisher Scientific, USA). The biogas sparging rate was fixed at $3.76 \pm 0.08 \mathrm{~L} / \mathrm{min}$ during the experiments by adjusting the digital pump speeds. At the bottom of the reactor, a gentle mixing was applied using a magnetic stirrer blade (Barnstead Thermolyne, Cimarec Plate Stirrer, Dubuque, IA, USA) to keep the reactor in suspension. For biogas composition measurement, the biogas samples were taken from the top reactor's port, while the biogas produced was collected in a graduated cylinder using a water displacement method. The reactor was operated at OLRs between 2.5 and $6.8 \mathrm{~kg}-\mathrm{COD} / \mathrm{m}^{3} \mathrm{~d}$ and hydraulic retention times (HRTs) in the 3-8 d range.

\subsection{Analytical methods}

\subsubsection{Primary sludge samples, reactor feeds, and inoculum}

Primary sludge was characterized for total solids (TS), total suspended solids (TSS), and volatile solids (VS) according to standard methods (Baird et al., 2017). TSS of the reactor feed and digestate was analyzed three times a week, while $\mathrm{pH}$ was monitored daily. Total COD of the permeate and feed were analyzed every alternate week, using HR COD test vials (K-7365, 0-1500 ppm) and a COD reactor (Hanna Instruments), followed by absorbance measurement using a colorimeter (Hach DR 2800 Spectrophotometer). Ash content in the sludge sample was measured after dry oxidation of PS at $575^{\circ} \mathrm{C}$ using a muffle furnace, according to standard methods for biomass analysis (Cai et al., 2017). The pH was measured using an Oakton pH 700 benchtop meter. Elemental composition (C, N, H, S, and O) was 
measured by an elemental analyzer (Elementar Vario EL). The inoculum was analyzed for TS, TSS, VS, $\mathrm{COD}$, ash, $\mathrm{pH}$, and elemental content as per the methods mentioned previously. Table 1 shows the results of the primary sludge, feed, and inoculum characterization. Air dry primary sludge contains $96.32 \pm 0.28$ $\%$ total solids, $93.93 \pm 0.24 \%$ volatile solids, and $6.07 \pm 0.244 \%$ fixed solids. The reduction of TSS and VSS is usually used as an indicator of the biodegradation efficiency of sludge. There is a linear relationship between SCOD solubilization and VSS reduction (Zhang et al., 2013), here the higher the solubilization of COD, the higher is the reduction of VSS.

Table 1

Characteristics of the primary sludge and thermophilic inoculum used in this study.

\begin{tabular}{|llll|}
\hline Item & Unit & Primary sludge & Mesophilic inoculum \\
\hline TSS & $(\mathrm{g} / \mathrm{L})$ & $11.54 \pm 0.42$ & $36.63 \pm 0.31$ \\
\hline TS & $(\mathrm{g} / \mathrm{L})$ & $11.80 \pm 0.65$ & $39.62 \pm 0.43$ \\
\hline VS & $(\% T S)$ & $93.93 \pm 0.24$ & $83.48 \pm 0.37$ \\
\hline $\mathrm{C}$ & $(\% \mathrm{TS})$ & $41.69 \pm 8.29$ & $43.66 \pm 0.60$ \\
\hline $\mathrm{H}$ & $(\% \mathrm{TS})$ & $6.19 \pm 0.60$ & $5.82 \pm 0.29$ \\
\hline O & $(\% \mathrm{TS})$ & $42.16 \pm 2.4$ & - \\
\hline $\mathrm{N}$ & $(\% \mathrm{TS})$ & $0.15 \pm 0.07$ & $3.25 \pm 0.10$ \\
\hline $\mathrm{S}$ & $(\% \mathrm{TS})$ & $0.05 \pm 0.03$ & $1.02 \pm 0.11$ \\
\hline $\mathrm{C} / \mathrm{N}$ & & 285.60 & 13.43 \\
\hline TCOD & $(\mathrm{g} / \mathrm{L})$ & $20.078 \pm 1.865$ & $47.66 \pm 1.04$ \\
\hline Soluble COD & $(\mathrm{g} / \mathrm{L})$ & $0.194 \pm 0.010$ & $1.150 \pm 0.100$ \\
\hline Ash & $(\%)$ & $3.61 \pm 0.37$ & $16.52 \pm 0.38$ \\
\hline pH & & $7.2 \pm 1$ & $6.99 \pm 0.030$ \\
\hline - = indicates not measured values & \\
\hline
\end{tabular}

\subsubsection{Biogas production and composition}

The biogas production rate was measured daily throughout the experimental period using the water displacement method and graduated cylinder, and then the biogas yields were calculated as weekly averages. Biogas composition (methane, nitrogen, and carbon dioxide) was measured by a gas chromatography system (Shimadzu, GC-2014, Kyoto Japan). The biogas samples were taken from the headspace of the bioreactor using a $5 \mathrm{ml}$ syringe and injected in the GC system equipped with a thermal conductivity detector (room temperature $+10^{\circ} \mathrm{C}$ to $400^{\circ} \mathrm{C}$ ), a silica gel packed column, and injectors. Helium was used as an equipment carrier gas at a flow rate of $30 \mathrm{~mL} \mathrm{~min}^{-1}$ (digital setting by electronic 
flow controller (AFC)). Samples were injected at room temperature via a single packed injector to determine the composition. The composition was measured every two days throughout the experimental period.

\subsubsection{Permeate quality and digestate properties}

COD of the permeate was measured according to the standard protocols (APHA, 2005) every other week. MLSS was measured three times a week and monitored throughout the experimental period. Elemental composition ( $\mathrm{C}, \mathrm{N}, \mathrm{H}, \mathrm{S}, \mathrm{O})$ of digestates was analyzed by an Elementar Vario EL ( $\mathrm{GmbH}$, Hanau, Germany). Chemical element concentrations of the permeate were measured by the ICP-AES (Inductively coupled plasma atomic emission spectroscopy) elemental analyzer. NanoBrook Zeta PALS Analyzer (Brookhaven Instruments Corp, USA) was used to analyze the zeta potential of digestates suspension. Structural changes and degradation of primary sludge components after anaerobic digestion were studied using a Bruker Tensor 37 Fourier Transform Infrared (FT-IR) Spectrophotometer. Digestates dewaterability was measured by Capillary Suction Time (CST) (Triton Electronics Ltd., Bigods Hall, Dunmow, UK), using CST filter paper and a $1 \mathrm{~cm}$ sludge funnel. Some measurements were performed throughout the experimental period, others were made in triplicate, and results were reported as means \pm standard deviations.

\subsubsection{Particle size distributions}

Mastersizer 2000 Particle Size Analyzer (Malvern Instruments Ltd. Worcestershire, UK) was used for the measurement of the particle size distributions of the mixed liquor and feed samples. It consists of an optical bench (to collect raw data), dispersion units (for sample preparation/delivery), and a standalone computer unit that runs Malvern software. This instrument uses laser diffraction or low light angle scattering and can measure particle sizes in the range of 0.02 to 2000 microns using a single optical measurement path. The mastersizer detects the scattered light, which is a combination of two light sources, by a detector that is used to measure across the particle size range and converts a signal to size. This device measures each sample three times automatically and calculates the average.

\section{Results And Discussion}

\section{Effect of OLR on biological performance and stability}

The biological performance was determined in this study based on biogas productivity/composition, permeate quality/digestate properties, and solids reduction. Table 2 shows the operating conditions of ThAnMBR. The experiment was divided into three phases as shown in Table 2. Phase I was operated at HRT of $5 \mathrm{~d}$ and OLR of $3.7 \mathrm{~kg}-\mathrm{COD} / \mathrm{m}^{3} \mathrm{~d}$, while phases II and III were operated at HRTs of 3 and $8 \mathrm{~d}$ and OLRs of 6.8 and $2.59 \mathrm{~kg}-\mathrm{COD} / \mathrm{m}^{3} \mathrm{~d}$, respectively. This study aims to test the feasibility of the primary sludge digestion under relatively higher organic loading rates and lower HRTs. Regarding the primary sludge studies, Bayr and Rintala (2012) studied primary sludge digestion under hydraulic retention times 
(HRT) in the range of 16-32 d, which is relatively high compared to the current study. Likewise, Veluchamy and Kalamdhad (2017b) investigated pulp and paper mill sludge digestion under HRT of $45 \mathrm{~d}$.

All phases of this study were run at a constant solid retention time of $32 \mathrm{~d}$. In all phases, the primary sludge was introduced as a sole substrate to examine its biogas potential and solids reduction. At the end of each phase, the reactor was shut down, and the membrane was taken out for characterization. To initiate each phase, the reactor was mixed, and a new membrane module was installed, then, the required HRT and OLR were set up. Each phase lasted for more than 3 months, once the reactor biogas production and MLSS concentration were stable, the reactor was shifted into the next operating conditions, as shown in Fig. $2(a-c)$. The system was operated in three different organic loading environments by changing the HRT (flow rate) while maintaining a constant SRT for the process.

Table 2

Digestion conditions of the primary sludge and process water in AnMBR.

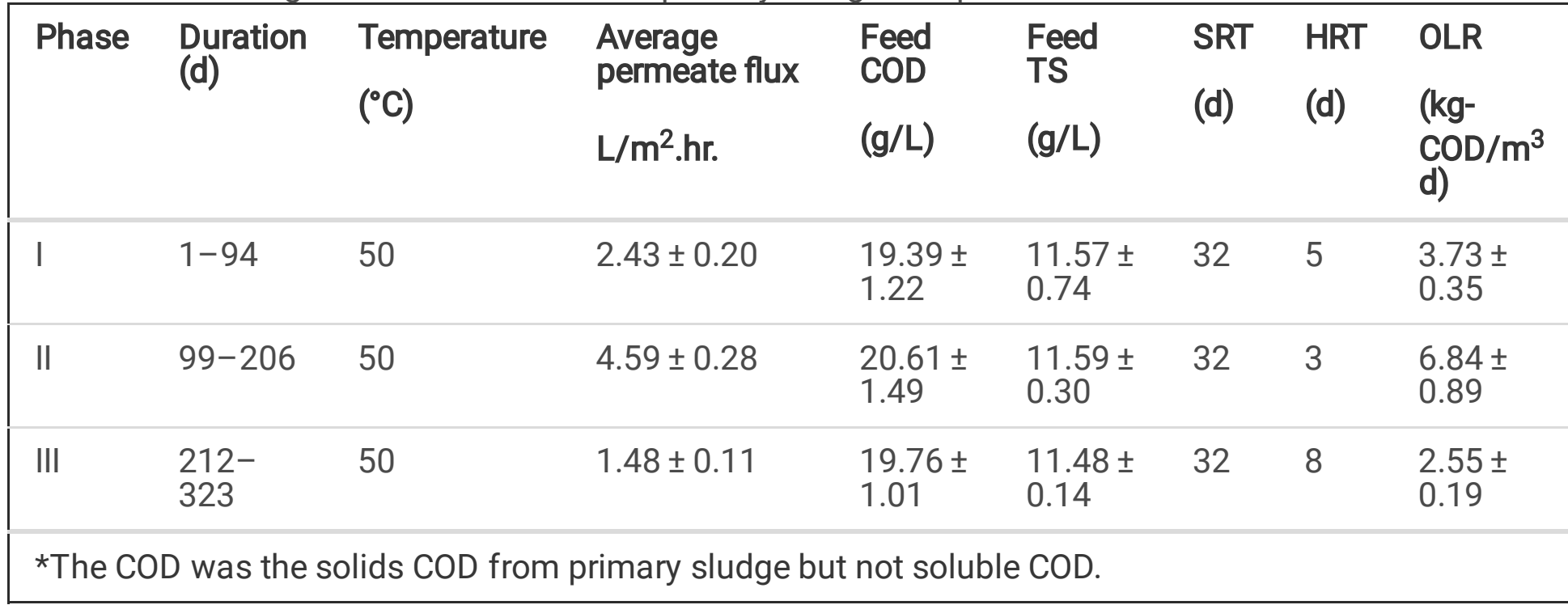

\subsection{Biogas production and composition}

Reportedly, optimal biogas yield is a result of appropriate reactor design and enhanced growth of methanogens forming bacteria, which in turn depends on the favorable operating environment (e.g., the optimal amount of feedstock (OLR), temperature, and HRT). Biogas production and percentage of biogas composition of different operating conditions studied are presented in Fig. $2(a-c)$. Reactor performance was studied at different OLR ranges from 2.5 to $6.8 \mathrm{~kg}-\mathrm{COD} / \mathrm{m}^{3} \mathrm{~d}$. The best results were obtained at higher HRTs and lower organic loading rates. At the beginning of each phase, a slight decrease in biogas yield was observed but the system soon recovered and adapted to new conditions over time. The average biogas production rate of the reactor for loading rates of $3.7 \pm 0.4,6.8 \pm 0.9$, and $2.5 \pm 0.1 \mathrm{~kg} \mathrm{COD} / \mathrm{m}^{3} \mathrm{~d}$ was observed as $0.96,1.14$, and $1.6 \mathrm{~L} / \mathrm{d}$, respectively (Fig. 2a). Best biogas productivity was achieved at OLR $2.5 \mathrm{~kg} \mathrm{COD} / \mathrm{m}^{3} \mathrm{~d}$ and HRT $8 \mathrm{~d}$. The biogas production at $2.5 \mathrm{~kg} \mathrm{COD} / \mathrm{m}^{3} \mathrm{~d}$ OLR was about two times higher than that at $3.7 \mathrm{~kg} \mathrm{COD} / \mathrm{m}^{3} \mathrm{~d}$ OLR. The system showed a decrease in biogas production with an increased loading rate. The increased solids content can be outside the capacity of microorganisms to handle it due to the recalcitrant nature of the primary sludge. A decrease in biogas 
production with an increase in OLR is observed in many previous findings. For example, Gou et al. (2014) observed an approximately 43\% decrease in $\mathrm{CH}_{4}$ yield when the OLR increased from 1 to $6 \mathrm{~g} \mathrm{VS} / \mathrm{L} /$ day, during the co-digestion of waste activated sludge with food waste in a thermophilic system. Hassan et al. (2015) reported a similar result when anaerobically treated recycled paper mill effluent by a hybrid baffled reactor. The biomass degradation was also decreased as OLR increased. Several studies have shown similar findings. For example, Mel et al. (2015) reported a reduced COD degradation as the organic loading increased. This can be attributed to the recalcitrant property of the primary sludge, which requires a longer residence time, and the overloading of the system. These results illustrate that it is not feasible to operate the system under the high solids rate of the primary sludge, and OLR $2.5 \mathrm{~kg} \mathrm{COD} / \mathrm{m}^{3} \mathrm{~d}$ and HRT $8 \mathrm{~d}$ may be consider optimum and can be suggested as design criteria for PS treatment. Different optimal OLRs are reported for anaerobic digestion of organic wastes, but this result is similar to results obtained by Liu et al. (2017) when they treated food waste under a thermophilic condition and an optimum OLR of 2.5 was reported. Figure $2 \mathrm{~b}$ shows biogas yield based on the amount of the feed suspended solids added. The average biogas production obtained during phase I at OLR of $3.7 \mathrm{~kg}$ $\mathrm{COD} / \mathrm{m}^{3} \mathrm{~d}$ was approximately $53 \mathrm{~L}$ biogas $/ \mathrm{kg}$ MLSS fed, however, when the OLR increased to $6.8 \mathrm{~kg}$ $\mathrm{COD} / \mathrm{m}^{3} \mathrm{~d}$ in phase II this resulted in a decreased biogas production of $45 \mathrm{~L}$ biogas $/ \mathrm{kg}$ MLSS fed. However, when OLR was reduced to $2.5 \mathrm{~kg} \mathrm{COD} / \mathrm{m}^{3} \mathrm{~d}$ in phase III this resulted in an improved biogas production of $155 \mathrm{~L}$ biogas $/ \mathrm{kg}$ MLSS fed. The biogas production at phase II is corresponding to biogas production of $45 \mathrm{~m}^{3} / \mathrm{t} \mathrm{VS}_{\text {removed, }}$ which is reported by Jokela et al. (1997) for primary sludge from the TMP mill using the Biochemical Methane Potential (BMP) test. For comparison, the reported biogas yield for Kraft pulp mill primary sludge under the same operating temperature (thermophilic conditions) was higher than the biogas yield from the thermomechanical pulp mill reported in this study. For example, Bayr and Rintala (2012) reported $190-230 \mathrm{~m}^{3} \mathrm{CH}_{4} / \mathrm{tVS}_{\text {fed }}$ methane yields for primary sludge from bleached Kraft mill under OLR of $1-1.4 \mathrm{kgVS} / \mathrm{m}^{3} \mathrm{~d}$ and HRT of $16-32 \mathrm{~d}$ using CSTR. The OLR used in this study showing an excellent biogas production rate was 2-2.5 times of the OLR used in the study of Bayr and Rintala (2012), demonstrating the advantages of the THAnMBR, as compared to conventional CRTR. Differences in biogas production can be attributed to the different pulping conditions between the Kraft and TMP plants, as well as the resulting sludge. In the TMP process, the fibers are produced by thermal treatment followed by mechanical refining, while the kraft process involves treating the wood chips with a hot mixture containing water, $\mathrm{NaOH}$, and $\mathrm{Na}_{2} \mathrm{~S}$, known as white liquor. Hence, kraft fiber is flexible and easily degradable fiber compared to TMP fiber. Also, the surface of the kraft fibers contains less amounts of lignin and extractives than the TMP fibers, and the wood extractives are well-known inhibitory compounds for biological processes.

Under the steady-state, the methane content of the biogas was around $55.5 \pm 5.78 \%$, while, carbon dioxide and nitrogen content were $31.3 \pm 6.3$ and $13.2 \pm 5.6$, respectively (Fig. 2c). No significant change in the methane content was observed with the change in the solid loading rate, but the profile of the biogas production rate was different. The methane content achieved in this study was close to the results of most lignocellulosic treatment studies. It has been reported that the percentage of methane and carbon 
dioxide in biogas is largely dependent on the feedstock processed as well as the duration and extent of bio-methanation over the retention period (Kavuma, 2013). The relatively high $\mathrm{CO}_{2}$ content in the produced biogas of this study can be a result of the presence of acidifying microorganisms in methanogens, which causes the accumulation of volatile fatty acids in the process (Wijekoon et al., 2011; Franke-Whittle et al., 2014). Usually, a high VFAs concentration reduces the $\mathrm{pH}$ value in the reactor and prevents methane formation due to the inhibition of the methanogenesis process.

\subsection{Permeate quality}

The effect of OLRs on effluent (permeate) characteristics was evaluated in this study. The effluent properties were analyzed in terms of COD concentration, $\mathrm{pH}$, and chemical element concentrations. Effluent COD and chemical element concentrations have fluctuated to some extent with OLRs in the experiment. In the first phase, the average effluent COD was $1.67 \pm 0.46 \mathrm{~g} / \mathrm{L}$ at OLR of $3.7 \mathrm{~kg}-\mathrm{COD} / \mathrm{m}^{3} \mathrm{~d}$ while the average concentration of the COD in the second and third phases were $0.70 \pm 0.34$ and $0.32 \pm$ $0.11 \mathrm{~g} / \mathrm{L}$ at OLRs of 6.8 and $2.59 \mathrm{~kg}-\mathrm{COD} / \mathrm{m}^{3} \mathrm{~d}$, respectively. As can be seen from Fig. 3 , the COD of the effluent fluctuated slightly in the first phase, which could be due to the beginning of the acclimatization of microorganisms to the new environment and the addition of the inoculation substance (inoculum). Thereafter, the COD concentration stabilized and varied between $0.16 \mathrm{~g} / \mathrm{L}$ and $0.6 \mathrm{~g} / \mathrm{L}$ throughout the experimental period. This trend has also been reported in other studies, for example, Lin et al. (2011) reported a high COD value ( $800 \mathrm{mg} / \mathrm{L})$ in the initial start-up period and a low COD value $(425 \mathrm{mg} / \mathrm{L})$ during the stable-state process of the submerged anaerobic membrane reactor (SAnMBR). A similar pattern was observed by Hafuka et al. (2019), they reported a gradual decrease in the effluent COD concentration in the range of $840-240 \mathrm{mg} / \mathrm{L}$. Sato et al. (2016) reported COD values in the effluent in the range of $510-251 \mathrm{mg} / \mathrm{L}$ for a membrane bioreactor treating sludge biomass. Hafuka et al. (2019) attributed the high COD concentration of the membrane filtrate in early operating time to the high concentration of soluble-COD of the seed sludge. The soluble COD of inoculum (seed sludge) was $1.2 \mathrm{~g} / \mathrm{L}$ in this study, which could also be linked to the high COD concentration in the first phase. COD concentration decreased with increasing operating time can also be attributed to an increase in biological activity in the reactor (high degradation rate).

On the other hand, the OLR has shown some influence on the effluent COD, where the lower OLR was associated with a lower COD concentration. This may indicate that the high solid loading rate is not fully digested by the reactor microorganisms. It is worth noting that the COD of the effluent at the lower OLR was to a certain extent stable compared to the higher OLRs. Higher effluent COD with higher OLRs was also reported in other research works. For example, Boonyungyuen et al. (2014) reported $132.0 \pm 4.3 \mathrm{mg} / \mathrm{L}$ effluent COD concentration for OLR of $0.52 \mathrm{~kg} / \mathrm{m}^{3} \mathrm{~d}$ compared to $84.4 \pm 10.2 \mathrm{mg} / \mathrm{L}$ for OLR of $0.13 \mathrm{~kg} / \mathrm{m}^{3}$ $\mathrm{d}$, when they treated textile wastewater by MBR. Wijekoon et al. (2011) attributed the higher permeate concentration to the increased generation of volatile fatty acid (VFA) on the reactor with increased OLR, and they achieved VFA removal efficiency in descending order of $96 \%, 94 \%$, and $82 \%$ for OLRs of 5,8 , and $12 \mathrm{~kg} \mathrm{COD} / \mathrm{m}^{3} \mathrm{~d}$, respectively. In this study, the $\mathrm{pH}$ of the effluent ranged from 7.2 to 7.4 , which is in the methanogenic range indicating the stability of the system. Concentrations of chemical elements differed 
slightly between the tested conditions (Table 3), where the permeates of the shorter HRTs had more concentrations of phosphorus, copper, sodium, and potassium, compared to the longer HRT permeate. However, the remaining elements did not differ greatly between the varied operating conditions. 
Table 3

Effluent characteristics under different SRTs

\begin{tabular}{|c|c|c|c|c|}
\hline \multirow[t]{2}{*}{ Description } & \multirow{2}{*}{$\begin{array}{l}\text { Minimum detection limit } \\
\text { (MDL) }\end{array}$} & \multicolumn{3}{|c|}{ Permeate properties at different HRTs } \\
\hline & & $5 d$ & $3 d$ & $8 d$ \\
\hline \multicolumn{5}{|c|}{ Macronutrients (mg/L) } \\
\hline Phosphorus & 0.05 & 100.5 & 100.7 & 73.83 \\
\hline Sulfur & 0.3 & 34.27 & 50.4 & 70.93 \\
\hline \multicolumn{5}{|c|}{ Micronutrients (mg/L) } \\
\hline Iron & 0.005 & 0.039 & 0.044 & 0.084 \\
\hline Cobalt & 0.002 & $<0.002$ & $<0.002$ & $<0.002$ \\
\hline Nickel & 0.03 & $<0.03$ & $<0.03$ & $<0.03$ \\
\hline Zinc & 0.001 & 0.0023 & 0.0023 & $<0.001$ \\
\hline Copper & 0.002 & 0.0073 & 0.0043 & $<0.0027$ \\
\hline Manganese & 0.001 & 0.034 & 0.040 & 0.057 \\
\hline Molybdenum & 0.05 & $<0.05$ & $<0.05$ & $<0.05$ \\
\hline Selenium & 0.05 & $<0.05$ & $<0.05$ & $<0.05$ \\
\hline \multicolumn{5}{|c|}{ Common cations (mg/L) } \\
\hline Sodium & 0.03 & 505 & 403.33 & 346.67 \\
\hline Potassium & 0.5 & 167 & 145 & 117.33 \\
\hline Calcium & 0.01 & 11.99 & 9.10 & 12.23 \\
\hline Magnesium & 0.01 & 3.16 & 2.92 & 3.49 \\
\hline Lead & 0.03 & $<0.03$ & $<0.03$ & $<0.03$ \\
\hline Aluminum & 0.03 & $<0.03$ & $<0.03$ & $<0.03$ \\
\hline Barium & 0.04 & $<0.04$ & $<0.04$ & $<0.04$ \\
\hline Chromium & 0.002 & 0.0053 & $<0.002$ & $<0.003$ \\
\hline Tin & 0.05 & $<0.05$ & $<0.05$ & $<0.05$ \\
\hline Strontium & 0.01 & 0.023 & $<0.01$ & 0.017 \\
\hline $\mathrm{COD}(\mathrm{mg} / \mathrm{L})$ & & $1.7 \pm 0.46$ & $0.70 \pm 0.34$ & $0.32 \pm 0.11$ \\
\hline $\mathrm{pH}$ & & $7.3 \pm 0.3$ & $7.2 \pm 0.1$ & $7.3 \pm 0.1$ \\
\hline
\end{tabular}


The performance of the system was assessed also by taking into consideration the digestate properties under different operating conditions of ThAnMBR. Figure 4 shows the concentrations of MLSS (mixed liquor suspended solids), FSS (Feed suspended solids), and reactor $\mathrm{pH}$ upon changing of different OLRs in the reactor. The MLSS concentrations for the reactor ranged from 16 to $28 \mathrm{~g} / \mathrm{L}$. The first phase showed fluctuation in MLSS concentration, which could be due to microorganisms' acclimatization (Fig. 4). In the second phase, the MLSS concentration increased from 20 to $24 \mathrm{~g} / \mathrm{L}$ due to the increased organic loading rate (from 3.7 to $6.8 \mathrm{~kg} \mathrm{COD} / \mathrm{m}^{3} \mathrm{~d}$ ) and stabilized at about $26 \mathrm{~g} / \mathrm{L}$ throughout the phase time. However, when the OLR was reduced to $2.5 \mathrm{~kg} \mathrm{COD} / \mathrm{m}^{3} \mathrm{~d}$ in the third phase, the MLSS concentration remained stable and high. The reason for this was the accumulation of sludge on the wall of the reactor at the liquid and biogas interface in the second phase, and the falling of the accumulated headspace sludge on the bioreactor at the end of the second phase resulted in a higher MLSS concentration in the following phase (third phase). The sludge accumulated in the headspace of the reactor in the second phase due to the high OLR coupled with reactor sparging by biogas for fouling control. The latter blew out the sludge into the reactor headspace and then the sludge accumulated on the headspace and between the fittings. Although a drop in MLSS concentrations was expected due to reduced OLR, the MLSS concentration in the third phase ranged between 25 and $26.5 \mathrm{~g} / \mathrm{L}$ because of the aforesaid reasons, and no major fluctuation was seen, as shown in Fig. 4.

In this study, the total solids of the treated sludge were $11.80 \pm 0.65$, and $\mathrm{NH}_{4} \mathrm{Cl}$ and $\mathrm{K}_{2} \mathrm{HPO}_{4}$ were added as nutrients to the feed to meet the COD:N:P ratio of 100:2.6:1. At this concentration, the bioreactor can be easily fed with the sludge substrate using a magnetic drive centrifugal pump (Iwaki magnetic pump). It has been reported that there is an optimal concentration of TS content in raw materials and usually ranges between $1-10 \%$ and that the volume of the produced biogas diminishes by reducing and increasing the TS concentration portion below and above the optimum value (Yavini et al., 2014; Dhar et al., 2016). The pH profile of the reactor during the experimental time is shown in Fig. 4. The pH of the system ranged between 7.2 and 7.5 in this study. Reportedly, the $\mathrm{pH}$ values and temperature regime have a direct impact on biogas production. Methanogens have been reported to grow better in the $\mathrm{pH}$ range 6.8-7.5, which is favorable for biogas production. However, the anaerobic digester process can tolerate a range of 6.5 to 8.0 (Cioabla et al., 2012). On the other hand, lower pH levels may lead to a complete reactor failure by inhibiting the $\mathrm{CH}_{4}$-forming bacteria.

Table 4 shows the properties of digestate under different operating conditions. The average soluble COD for digestates was $0.188,0.326$, and $0.153 \mathrm{~g} / \mathrm{L}$ in phase I, II, and III, respectively. The soluble COD of the digestate was higher in the third phase compared to the first (HRT, $5 \mathrm{~d}$ ) and second (HRT, $8 \mathrm{~d}$ ) phases. This may be due to the short HRT ( $3 \mathrm{~d})$, which corresponds to the highest OLR $\left(6.8 \mathrm{kgCOD} / \mathrm{m}^{3} \mathrm{~d}\right)$. Elemental composition ( $\mathrm{C}, \mathrm{N}, \mathrm{H}$, and $\mathrm{S}$ ) was analyzed by an elemental analyzer. As can be seen from Table 4, there is no significant difference in $\mathrm{C}, \mathrm{N}, \mathrm{H}$, and $\mathrm{S}$ concentrations between the tested OLRs. However, nitrogen concentration decreased slightly with increasing digestion time. It can be concluded from Table 4 that digestates contain high carbon sources and low nutrient sources. Thereby, for the further valorization of this digestate via bioconversion processes, the value of these two crucial elements 
needs to be optimized for improved microorganisms' growth and degradation rate. As indicated in Table 4, the weekly average of the biogas yield ranged between 0.061 and $0.095 \mathrm{~L}$ biogas/g MLSS removed in the first phase and ranged between 0.045 and 0.059 in the second phase. Whereas the biogas yield in the third phase was in the range of $0.316-0.339 \mathrm{~L}$ biogas/g MLSS removed, indicating the effect of OLR on the biogas yield and a lower OLR led to an increased biogas yield.

Solid's reduction ratio is an important parameter in the anaerobic digestion of sludge. The reduction of the sludge biomass ranged from 28.9 to $46.7 \%$ in this study, depending on the applied OLRs. Sludge biomass degradation efficiency decreased with increasing OLR. Sludge biomass reduction was $45.5 \%$ at the OLR of $3.7 \mathrm{~kg} \mathrm{COD} / \mathrm{m}^{3} \mathrm{~d}$ but was markedly reduced to $28.9 \%$ when the OLR increased to $6.8 \mathrm{~kg}$ $\mathrm{COD} / \mathrm{m}^{3} \mathrm{~d}$. While the solids reduction in the reactor varied between 46.13 and $46.7 \%$ for the OLR of $2.5 \mathrm{~kg}$ $\mathrm{COD} / \mathrm{m}^{3} \mathrm{~d}$. This result is similar to the previously reported results for MBRs. For example, Sato et al. (2016) achieved about $47.4 \%$ sludge biomass reduction when the OLR was reduced from 0.45 to 0.225 $\mathrm{kg} \mathrm{COD} / \mathrm{m}^{3} \mathrm{~d}$, using pilot-scale MBR. Using conventional bioreactors, Lin et al. (2009) reported cellulose degradation efficiency in the range of 21.8 to $65 \%$ for pulp and paper sludge, but no pronounced change was observed for lignin degradation even after $\mathrm{NaOH}$ pretreatment, indicating the low degradability of the lignin. Bayr and Rintala (2012) achieved cellulose removal efficiency in the range of 70-73\% after anaerobic digestion of pulp and paper primary sludge with overall volatile solids (VS) removal between 25 and $40 \%$ (similar to the results from this study), but hemicellulose did not degrade much compared to cellulose with a degradation efficacy between 7 and 27\%. Kinnunen et al. (2015) reported VS removal between 11 and $26 \%$ for pulp and paper industry bio-sludge, which is similar to the finding $(9-23 \% \mathrm{VS}$ removal) reported by Saha et al. (2011) for pulp and paper mill secondary sludge. Thus, for improved organic matter degradation, pretreatment of the sludge substrate could be recommended. 
Table 4

Digestates properties biogas yield, and solids reduction ratio under different operating conditions of anaerobic digestion of pulp and paper mill primary sludge in thermophilic AnMBR.

\begin{tabular}{|c|c|c|c|}
\hline \multirow[t]{2}{*}{ Component } & \multicolumn{3}{|c|}{ Digestate characteristics at different phases } \\
\hline & Phase I & Phase II & Phase III \\
\hline Days & $1-94$ & $99-206$ & $212-323$ \\
\hline $\operatorname{OLR}\left(\mathrm{kgCOD} / \mathrm{m}^{3} \mathrm{~d}\right)$ & 3.7 & 6.8 & 2.5 \\
\hline HRT (d) & 5 & 3 & 8 \\
\hline SRT (d) & 32.5 & 32.5 & 32.5 \\
\hline Nitrogen addition ${ }^{a}$ & yes & yes & yes \\
\hline Phosphorus addition ${ }^{b}$ & yes & yes & yes \\
\hline VS (\%) & $90.18 \pm 0.39$ & $92.83 \pm 1.2$ & $92.35 \pm 0.64$ \\
\hline Fixed solids (\%) & $9.82 \pm 0.38$ & $7.17 \pm 1.2$ & $7.65 \pm 0.65$ \\
\hline $\operatorname{SCOD}(g / l)$ & $0.188 \pm 0.007$ & $0.326 \pm 0.009$ & $0.153 \pm 0.058$ \\
\hline Biogas yield (L biogas/g MLSS removed $)$ & 0.095 & 0.059 & 0.334 \\
\hline Average methane conc. (\%) & 55 & 58.7 & 56 \\
\hline Solid reduction (\%) & $45.5 \pm 0.74$ & $28.9 \pm 0.02$ & $46.13 \pm 0.95$ \\
\hline C (\%) & $45.22 \pm 1.26$ & $45.59 \pm 0.70$ & $45.07 \pm 1.20$ \\
\hline$H(\%)$ & $5.98 \pm 0.50$ & $5.94 \pm 0.15$ & $6.01 \pm 0.48$ \\
\hline $\mathrm{N}(\%)$ & $0.86 \pm 0.18$ & $0.79 \pm 0.24$ & $0.75 \pm 0.15$ \\
\hline S (\%) & $0.29 \pm 0.08$ & $0.25 \pm 0.06$ & $0.24 \pm 0.07$ \\
\hline $\mathrm{C} / \mathrm{N}$ & 52.58 & 57.71 & 60.09 \\
\hline $\mathrm{pH}$ & $7.2 \pm 0.10$ & $7.2 \pm 0.05$ & $7.2 \pm 0.09$ \\
\hline${ }^{\mathrm{a}} \mathrm{NH}_{4} \mathrm{Cl}$ & & & \\
\hline
\end{tabular}

\subsection{Particle size distribution}

The particle size distribution (PSD) measurement of the digestates is shown in Fig. 5. The PSD of the digestates did not vary greatly with different operating conditions (OLRs), as they ranged between 1 and 1000 microns. The second phase contained larger particles (peaked at about 500 microns) than the other 
phases, possibly due to the higher loading rate $\left(\mathrm{OLR}, 6.8 \mathrm{~kg} \mathrm{COD} / \mathrm{m}^{3} \mathrm{~d}\right)$. The other phases had OLRs in the range of $2.5-3.7 \mathrm{~kg} \mathrm{COD} / \mathrm{m}^{3} \mathrm{~d}$. All phases showed low amounts of small particles, which peaked at about $0.8 \mu \mathrm{m}$. The average size of the digestates of the different phases was around $30 \mu \mathrm{m}$. On the other hand, the size of the digestates molecules did not appear to have any clear effect on the membrane pores blocking, and this may be due to their large sizes. The employed membrane has a pore size of $0.1 \mu \mathrm{m}$, and it is well known that when the pore size is relatively small, fouling may result mainly from the foulants adsorption. It has been reported that when foulants are similar or smaller than the pores of the membrane, adsorption and pore-blocking mechanisms occur; however, when the foulants are greater than the pores of the membrane, a cake layer will likely form on the surface of the membrane (Bokhary et al., 2018).

\section{Conclusion}

In this study, thermophilic anaerobic digestion of primary sludge of a thermomechanical pulp mill in a relatively new type of bioreactor (ThAnMBR) was studied for the first time. In particular, the variations of OLRs with operational parameters and their interrelations were investigated. The results of this study showed that the primary sludge of the TMP mill can be satisfactorily treated with a ThAnMBR. The reactor showed stable performance and biogas production in the range of $0.059-0.334 \mathrm{~L}$ biogas $/ \mathrm{g} \mathrm{MLSS}$ removed was achieved. Lower OLRs and higher HRTs have been associated with higher biogas production compared to higher OLR and shorter HRT, and OLR of $2.5 \mathrm{~kg} \mathrm{COD} / \mathrm{m}^{3} \mathrm{~d}$ and HRT $8 \mathrm{~d}$ could be considered optimum and can be suggested as design criteria for PS treatment. The reduction of the sludge biomass ranged from 28.9 to $46.7 \%$ depending on the applied OLRs. Sludge biomass degradation efficiency decreased with increasing OLR. Also, changing the OLRs has shown some influence on the effluent COD, where the lower OLR was associated with a lower COD concentration. Similarly, digestate properties have fluctuated to some extent with OLRs. Regardless of OLRs, membrane performance was stable, and the required membrane flux was easily maintained during the operation. The results demonstrated that ThAnMBR is a promising new technology for pulp and paper mill primary sludge treatment and has many advantages as compared to conventional bioreactors.

\section{Declarations}

\section{Acknowledgements}

This research was financially supported by Ontario Graduate Scholarship (OGS) and Natural Sciences and Engineering Research Council of Canada (NSERC).

\section{References}

1. Baird RB, Eaton AD, Rice EW (2017). Standard methods for the examination of water and wastewater, 23rd Edition, American Public Health Association, American Water Works Association, Water 
Environment Federation, Washington DC.

2. Bajpai P (2015) Management of pulp and paper mill waste. Springer International Publishing.

3. Bayr S, Kaparaju P, Rintala J (2013) Screening pretreatment methods to enhance thermophilic anaerobic digestion of pulp and paper mill wastewater treatment secondary sludge. Chem Eng J 223: 479-486. https://doi.org/10.1016/j.cej.2013.02.119

4. Bayr S, Rintala J (2012) Thermophilic anaerobic digestion of pulp and paper mill primary sludge and co-digestion of primary and secondary sludge. Water Res 46: 4713-4720. https://doi.org/10.1016/j.watres.2012.06.033

5. Bokhary A, Maleki E, Hong Y, Hai FI, Liao B (2020) Anaerobic membrane bioreactors: Basic process design and operation. In: Ngo H, Guo W, Ng H, Mannina G, Pandey A (ed) Current Developments in Biotechnology and Bioengineering, $1^{\text {st }}$ edn. Elsevier, pp. 25-54. https://doi.org/10.1016/B978-0-12819852-0.00002-6

6. Bokhary A, Tikka A, Leitch M, Liao B (2018) Membrane fouling prevention and control strategies in pulp and paper industry applications: A review. J Membr Sci Res 4: 181-197. https://doi.org/10.22079/jmsr.2018.83337.1185

7. Boonyungyuen W, Wonglertarak W, Wichitsathian B (2014) Effect of organic loading rate on the performance of a membrane bioreactor (MBR) treating textile wastewater. In Proceedings of the International Conference on Chemical, Environment and Biological Sciences, Kuala Lumpur, Malaysia.

8. Cai J, He Y, Yu X, Banks SW, Yang Y, Zhang X, Yu Y, Liu R, Bridgwater AV, (2017) Review of physicochemical properties and analytical characterization of lignocellulosic biomass. Renewable Sustainable Energy Rev. 76: 309-322. https://doi.org/10.1016/j.rser.2017.03.072

9. Cioabla AE, Ionel I, Dumitrel GA, Popescu F (2012) Comparative study on factors affecting anaerobic digestion of agricultural vegetal residues. Biotechnol Biofuels 5: 1-9. https://doi.org/10.1186/17546834-5-39

10. Dereli R, K, Ersahin M.E, Ozgun H, Ozturk I, Jeison D, van der Zee F, van Lier J, B (2012) Potentials of anaerobic membrane bioreactors to overcome treatment limitations induced by industrial wastewaters. Bioresour Technol 122: 160-170. https://doi.org/10.1016/j.biortech.2012.05.139

11. Dhar H, Kumar P, Kumar S, Mukherjee S, Vaidya AN (2016) Effect of organic loading rate during anaerobic digestion of municipal solid waste. Bioresour Technol 217: 56-61. https://doi.org/10.1016/j.biortech.2015.12.004

12. Elliott A, Mahmood T (2012) Comparison of mechanical pretreatment methods for the enhancement of anaerobic digestion of pulp and paper waste activated sludge. Water Environ Res 84: 497-505. https://doi.org/10.2175/106143012X13347678384602

13. Elliott A, Mahmood T (2012) Comparison of mechanical pretreatment methods for the enhancement of anaerobic digestion of pulp and paper waste activated sludge. Water Environ. Res. 84: 497-505. https://doi.org/10.2175/106143012X13347678384602 
14. Franke-Whittle, IH, Walter, A, Ebner, C, Insam, H (2014) Investigation into the effect of high concentrations of volatile fatty acids in anaerobic digestion on methanogenic communities. J. Waste Manag. 34: 2080-2089. https://doi.org/10.1016/j.wasman.2014.07.020.

15. Gou C, Yang Z, Huang J, Wang H, Xu H, Wang L (2014) Effects of temperature and organic loading rate on the performance and microbial community of anaerobic co-digestion of waste activated sludge and food waste. Chemosphere 105: 146-151. https://doi.org/10.1016/j.chemosphere.2014.01.018

16. Gurram RN, Al-Shannag M, Lecher NJ, Duncan SM, Singsaas EL, Alkasrawi M (2015) Bioconversion of paper mill sludge to bioethanol in the presence of accelerants or hydrogen peroxide pretreatment. Bioresour Technol 192: 529-539. https://doi.org/10.1016/j.biortech.2015.06.010

17. Hafuka A, Mashiko R, Odashima R, Yamamura H, Satoh H, Watanabe Y (2019) Digestion performance and contributions of organic and inorganic fouling in an anaerobic membrane bioreactor treating waste activated sludge. Bioresour Technol 272: 63-69. https://doi.org/10.1016/j.biortech.2018.09.147

18. Hagelqvist A, (2013) Sludge from pulp and paper mills for biogas production: Strategies to improve energy performance in wastewater treatment and sludge management (Doctoral dissertation, Karlstads universitet).

19. Hassan SR, Zaman NQ, Dahlan I (2015) Effect of organic loading rate on anaerobic digestion: Case study on recycled paper mill effluent using Modified Anaerobic Hybrid Baffled (MAHB) reactor. KSCE J Civ Eng 19: 1271-1276. https://doi.org/10.1007/s12205-015-0746-9

20. Hazarika J, Khwairakpam M, (2018) Evaluation of biodegradation feasibility through rotary drum composting recalcitrant primary paper mill sludge. Waste Manag 76: 275-283. https://doi.org/10.1016/j.wasman.2018.03.044

21. Jiang, S., (2018) Thermophilic anaerobic membrane bioreactor for pulp and paper sludge treatment. Dissertation, Lakehead University Knowledge Commons.

22. Jokela J, Rintala J, Oikari A, Reinikainen O, Mutka K, Nyrönen T (1997) Aerobic composting and anaerobic digestion of pulp and paper mill sludges. Water Sci Technol 36: 181-188. https://doi.org/10.1016/S0273-1223(97)00680-X

23. Karlsson A, Truong XB, Gustavsson J, Svensson BH, Nilsson F, Ejlertsson J (2011) Anaerobic treatment of activated sludge from Swedish pulp and paper mills-biogas production potential and limitations. Environ Technol 32: 1559-1571. https://doi.org/10.1080/09593330.2010.543932

24. Kavuma C (2013) Variation of methane and carbon dioxide yield in a biogas plant. Dissertation, Royal Institute of Technology.

25. Kinnunen V, Ylä-Outinen A, Rintala J (2015) Mesophilic anaerobic digestion of pulp and paper industry biosludge-long-term reactor performance and effects of thermal pretreatment. Water Res 87: 105-111. https://doi.org/10.1016/j.watres.2015.08.053

26. Mel M, Mohd Suhuli N, Ihsan SI, Ismail AF, Yaacob S (2015) Effect of organic loading rate (OLR) of slurry on biogas production quality. In Advanced Materials Research 1115: 325-330. 
https://doi.org/10.4028/www.scientific.net/AMR.1115.325

27. Liew CS, Kiatkittipong W, Lim JW, Lam MK, Ho YC, Ho CD, Ntwampe SK, Mohamad M, Usman A (2021) Stabilization of heavy metals loaded sewage sludge: Reviewing conventional to state-of-theart thermal treatments in achieving energy sustainability. Chemosphere, 277: 130310. https://doi.org/10.1016/j.chemosphere.2021.130310

28. Likon M, Polonca T (2012) Recent advances in paper mill sludge management. In: Show KY, Xinxin G (ed) Industrial waste. InTech, pp. 73-90. https://doi.org/10.5772/37043

29. Lin H, Liao BQ, Chen J, Gao W, Wang L, Wang F, Lu X (2011) New insights into membrane fouling in a submerged anaerobic membrane bioreactor based on characterization of cake sludge and bulk sludge. Bioresour Technol 102: 2373-2379. https://doi.org/10.1016/j.biortech.2010.10.103

30. Lin Y, Wang D, Wu S, Wang C (2009) Alkali pretreatment enhances biogas production in the anaerobic digestion of pulp and paper sludge. J Hazard Mater 170: 366-373. https://doi.org/10.1016/j.jhazmat.2009.04.086

31. Liu C, Wang W, Anwar N, Ma Z, Liu G, Zhang R (2017) Effect of organic loading rate on anaerobic digestion of food waste under mesophilic and thermophilic conditions. Energ Fuel 31: 2976-2984. https://doi.org/10.1021/acs.energyfuels.7b00018

32. Lopes ADCP, Silva CM, Rosa AP, de Ávila Rodrigues F (2018) Biogas production from thermophilic anaerobic digestion of kraft pulp mill sludge. Renew Energy 124: 40-49. https://doi.org/10.1016/j.renene.2017.08.044

33. Manwatkar P, Dhote L, Pandey RA, Middey A, Kumar S (2021) Combustion of distillery sludge mixed with coal in a drop tube furnace and emission characteristics. Energy, 221: 119871. https://doi.org/10.1016/j.energy.2021.119871

34. Meyer T, Amin P, Allen DG, Tran H, (2018) Dewatering of pulp and paper mill biosludge and primary sludge. J. Environ. Chem. Eng 6: 6317-6321. https://doi.org/10.1016/j.jece.2018.09.037

35. Park ND, Helle SS, Thring RW (2012) Combined alkaline and ultrasound pre-treatment of thickened pulp mill waste activated sludge for improved anaerobic digestion. Biomass Bioenergy 46: 750-756. https://doi.org/10.1016/j.biombioe.2012.05.014

36. Pio DT, Tarelho LAC, Nunes TFV, Baptista MF, Matos MAA (2020a) Co-combustion of residual forest biomass and sludge in a pilot-scale bubbling fluidized bed. J Clean Prod 249: 119309. https://doi.org/10.1016/j.jclepro.2019.119309

37. Pio DT, Tarelho LAC, Pinto PR (2020b) Gasification-based biorefinery integration in the pulp and paper industry: A critical review. Renewable Sustainable Energy Rev 133: 110210. https://doi.org/10.1016/j.rser.2020.110210

38. Saha M, Eskicioglu C, Marin J (2011) Microwave, ultrasonic and chemo-mechanical pretreatments for enhancing methane potential of pulp mill wastewater treatment sludge. Bioresour Technol 102: 7815-7826. https://doi.org/10.1016/j.biortech.2011.06.053

39. Sato Y, Hori T, Navarro RR, Naganawa R, Habe H, Ogata A (2016) Effects of organic-loading-rate reduction on sludge biomass and microbial community in a deteriorated pilot-scale membrane 
bioreactor. Microbes Environ 31: 361-364. https://doi.org/10.1264/jsme2.ME16015

40. Simão L, Hotza D, Raupp-Pereira, F, Labrincha JA, Montedo ORK, (2018) Wastes from pulp and paper mills-a review of generation and recycling alternatives. Cerâmica, 64: 443-453.

https://doi.org/10.1590/0366-69132018643712414

41. Teghammar A, Castillo MDP, Ascue J, Niklasson C, Sárvári Horváth (2012) Improved anaerobic digestion by the addition of paper tube residuals: pretreatment, stabilizing, and synergetic effects. Energ Fuel 27: 277-284. https://doi.org/10.1021/ef301633x

42. Veluchamy C, Kalamdhad AS, (2017a) Influence of pretreatment techniques on anaerobic digestion of pulp and paper mill sludge: A review. Bioresour. Technol 245: 1206-1219. https://doi.org/10.1016/j.biortech.2017.08.179.

43. Veluchamy C, Kalamdhad AS (2017a) Biochemical methane potential test for pulp and paper mill sludge with different food/microorganisms ratios and its kinetics. Int. Biodeterior 117: 197-204. https://doi.org/10.1016/j.ibiod.2017.01.005

44. Wijekoon KC, Visvanathan C, Abeynayaka A (2011) Effect of organic loading rate on VFA production, organic matter removal and microbial activity of a two-stage thermophilic anaerobic membrane bioreactor. Bioresour Technol 102: 5353-5360. https://doi.org/10.1016/j.biortech.2010.12.081

45. Yavini TD, Chia Al, John A (2014) Evaluation of the effect of total solids concentration on biogas yields of agricultural wastes. Int Res J Environ Sci 3: 70-75.

46. Yin Y, Yin H, Yuan Z, Wu Z, Zhang W, Tian H, Feng L, Cheng S, Qing M, Song Q (2021) Study on the Pyrolysis Characteristics, Kinetics and Mineral Transformation of Paper Sludge. BioEnerg Res 20: 111. https://doi.org/10.1007/s12155-021-10248-6

47. Zhang L, Li W, Lu J, Li R, Wu Y (2021) Production of platform chemical and bio-fuel from paper mill sludge via hydrothermal liquefaction. J Anal Appl Pyrolysis 155: 105032. https://doi.org/10.1016/j.jaap.2021.105032

48. Zhang Y, Zhang P, Guo J, Ma W, Fang W, Ma B, Xu X (2013) Sewage sludge solubilization by highpressure homogenization. Water Sci Technol 67: 2399-2405. https://doi.org/10.2166/wst.2013.141

\section{Figures}




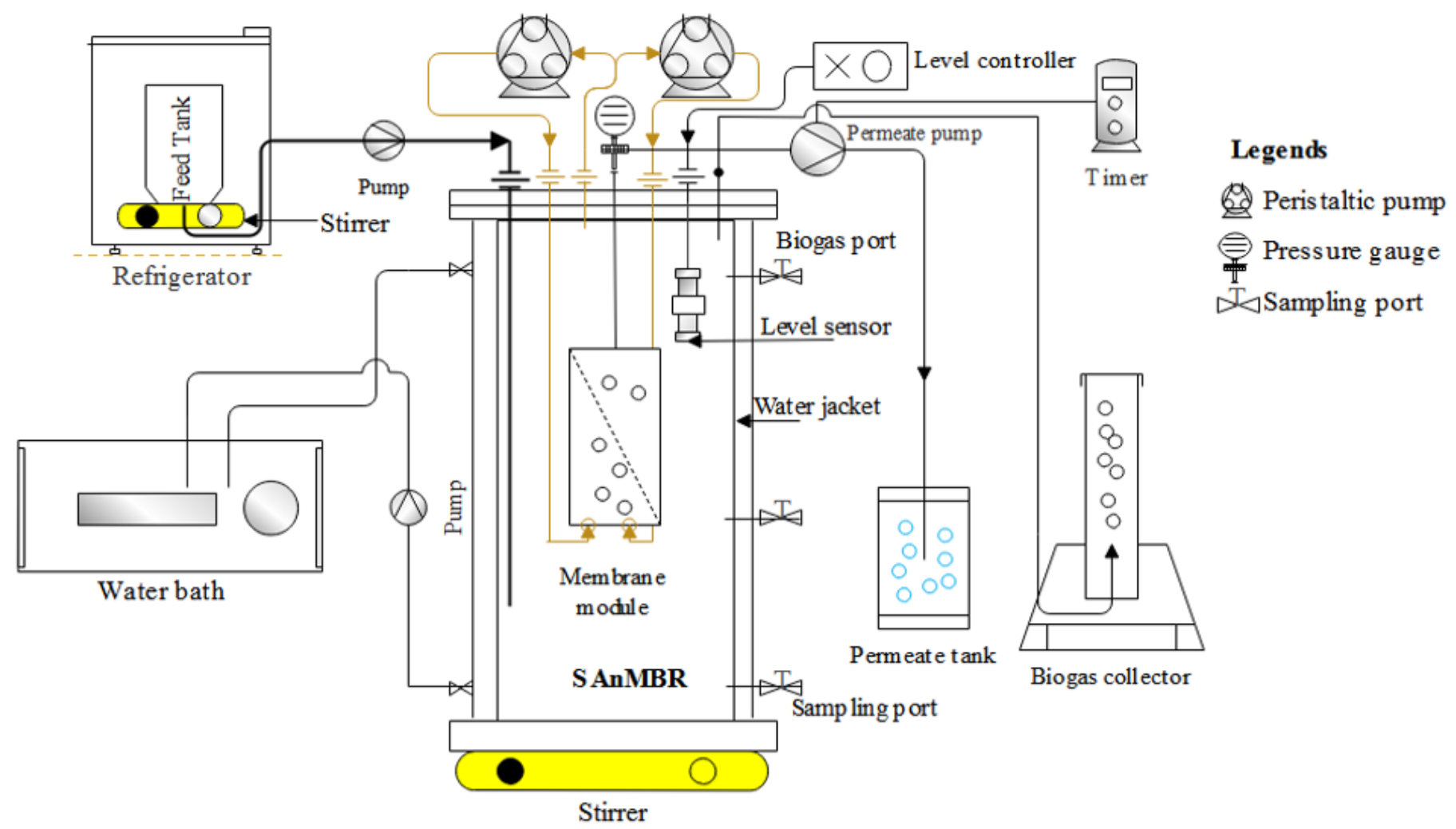

Figure 1

a schematic diagram of the ThAnMBR setup 

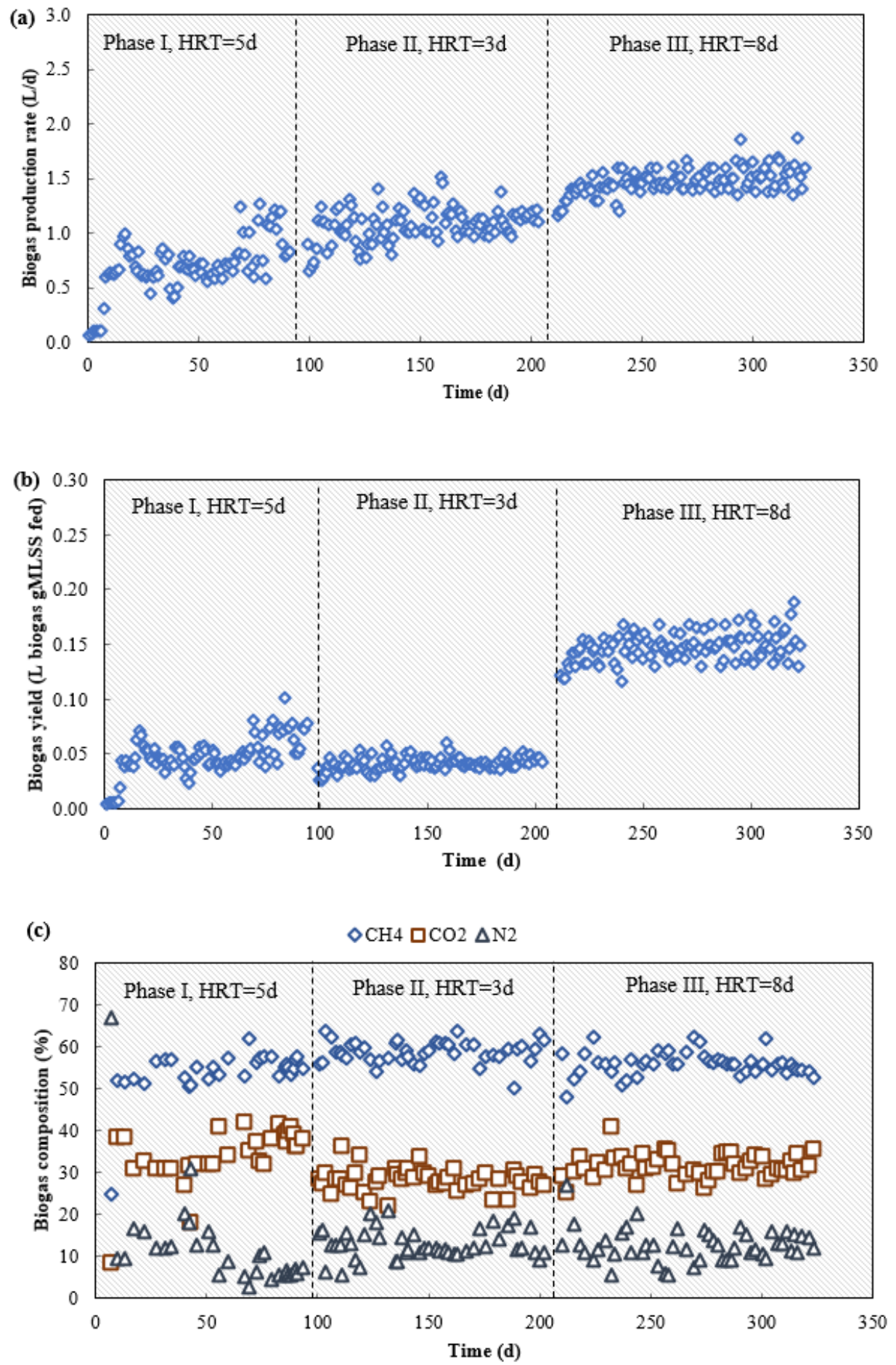

\section{Figure 2}

(a) Biogas production rate (b) biogas yield based on the amount of the feed suspended solids added (c) percentage of biogas composition at different organic loading rates over digestion time. 
$\Delta$ Permeate COD $(\mathrm{g} / \mathrm{L}) \quad \diamond$ Permeate $\mathrm{pH}$

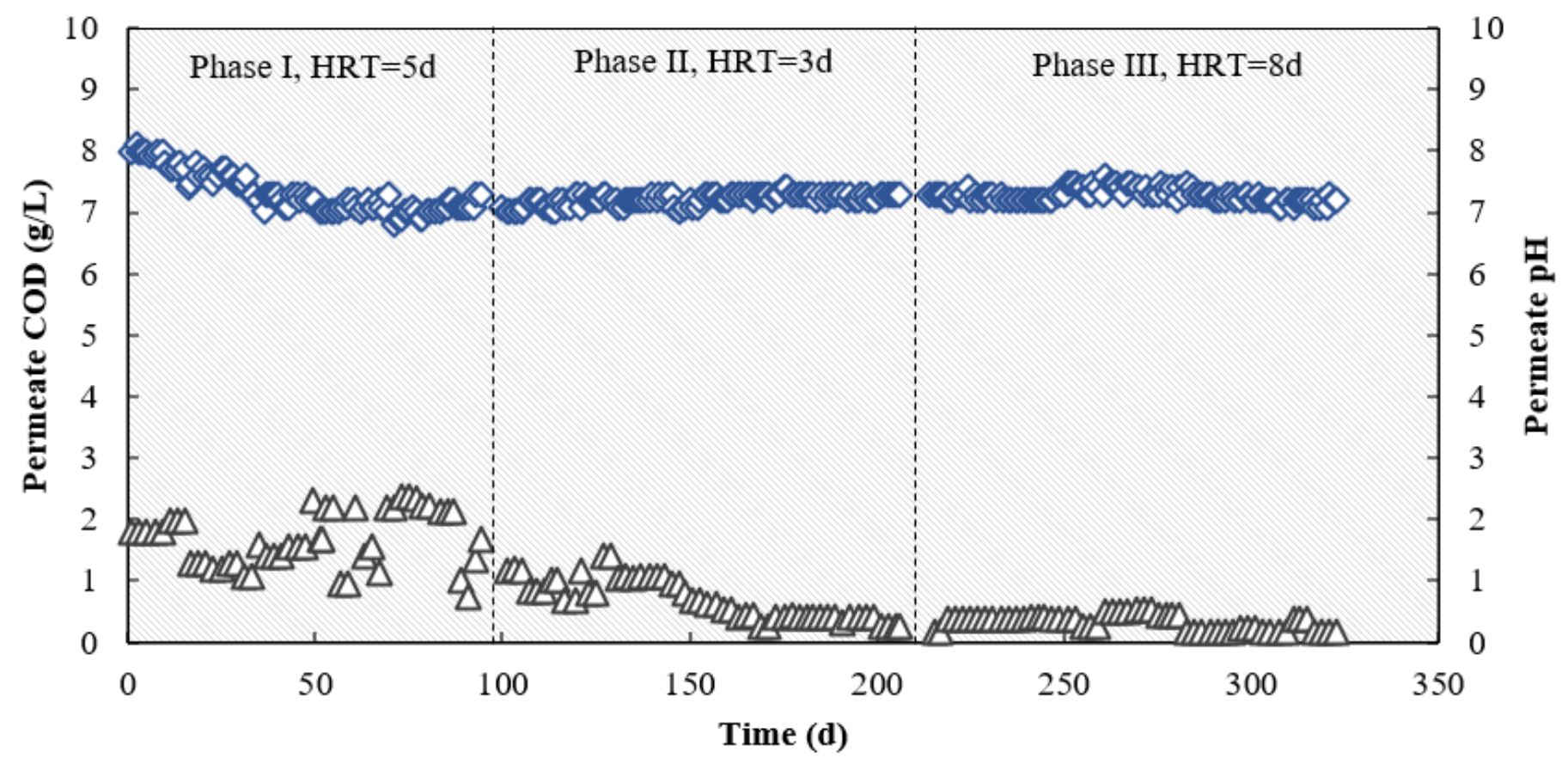

Figure 3

Permeate COD and $\mathrm{pH}$ under the tested conditions over digestion time.

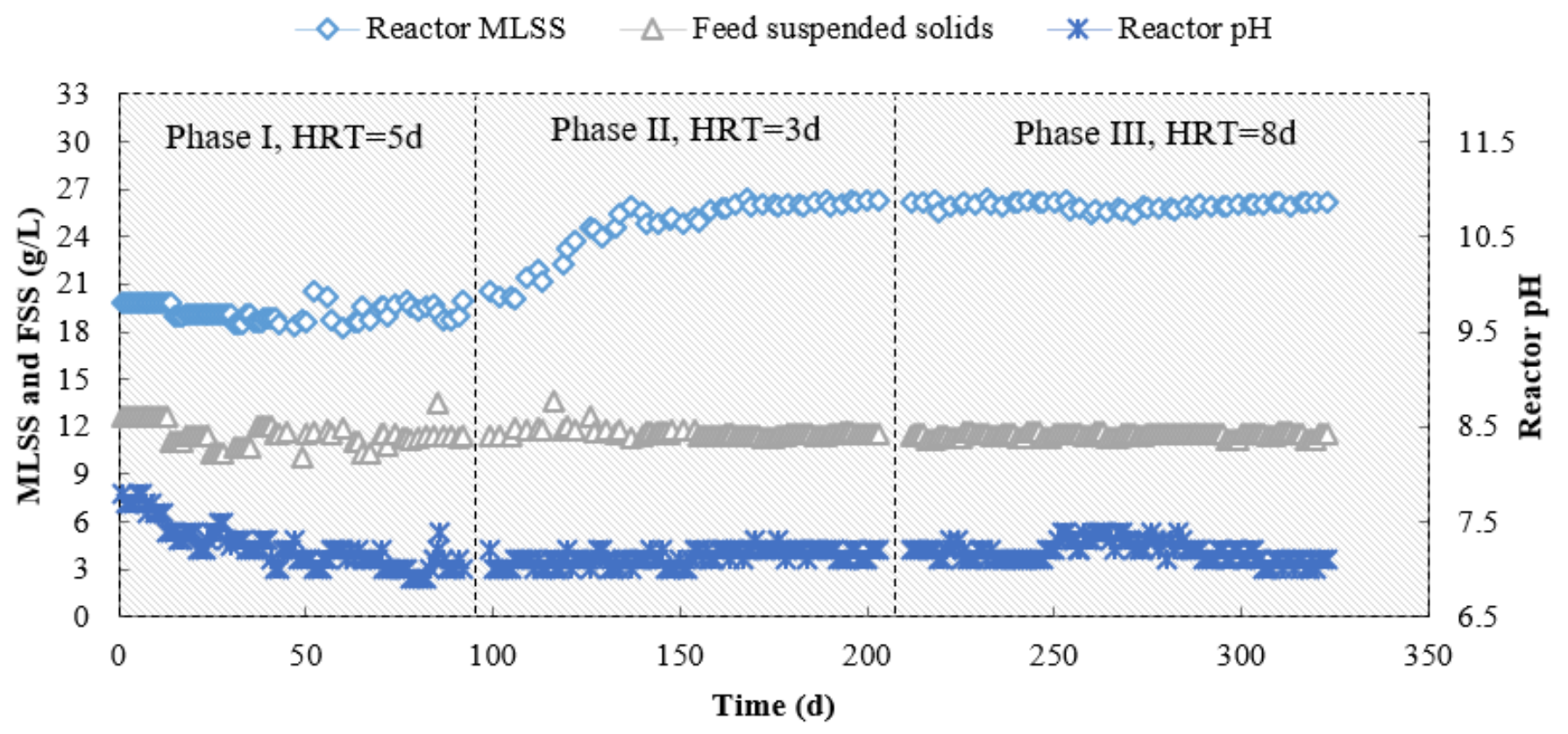

Figure 4

Mixed liquor suspended solids (MLSS) and pH of the digester and the suspended solids of the feeding substrate (FSS). 


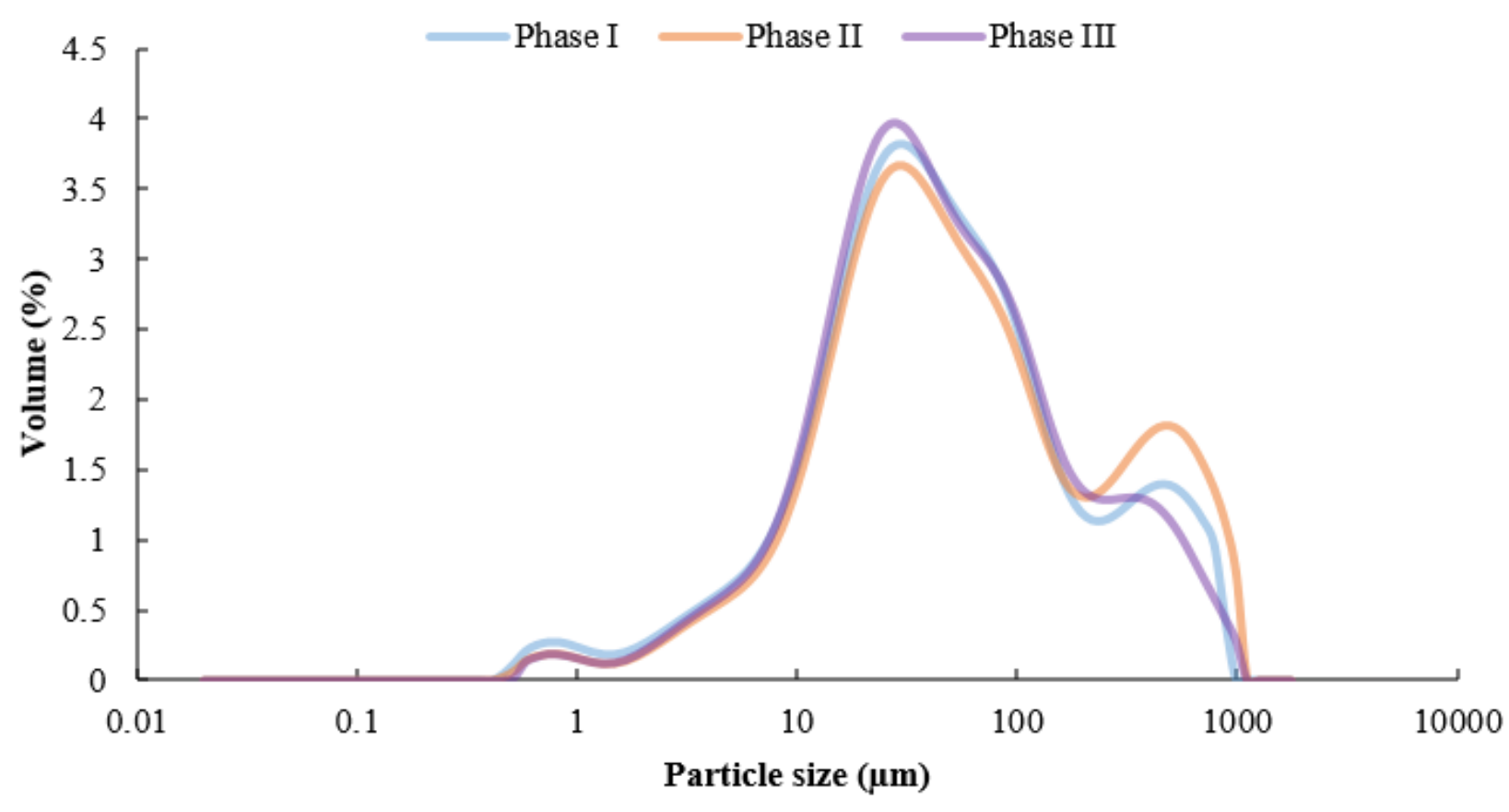

Figure 5

Particle size distribution of the mixed liquor suspended solids in the three tested conditions.

\section{Supplementary Files}

This is a list of supplementary files associated with this preprint. Click to download.

- GraphicalAbstract.docx 